Dmitry N. Samchenko ${ }^{1}$, PhD, Senior Researcher

ORCID ID 0000-0003-3305-8180 e-mail: sama30071988@gmail.com

Leonid I. Potapenko², $\mathrm{PhD}$, Senior Researcher

ORCID ID 0000-0003-0176-6094 e-mail: lpotapenko@ukr.net

Gennadii M. Kochetov ${ }^{1}$, D. S. (Engineering), Professor

ORCID ID 0000-0003-0041-7335 e-mail: gkochetov@ gmail.com

Oleksandr Y. Kovalchuk ${ }^{1}$, PhD, Senior Researcher

ORCID ID 0000-0001-6337-0488 e-mail: kovalchuk.oyu@gmail.com

Aleksey Vasiliev ${ }^{3}$, Dr., Professor

ORCID ID 0000-0003-2687-0672 e-mail: vasiliev@etsu.edu

Oksana M. Nechipor ${ }^{1}$, PhD, Assistant

ORCID ID 0000-0001-8635-2231 e-mail: okschena@ukr.net

${ }^{1}$ Kyiv National University of Construction and Architecture, Kyiv, Ukraine

${ }^{2}$ Taras Shevchenko National University of Kyiv, Kyiv, Ukraine

${ }^{3}$ East Tennessee State University, Johnson City, USA

\title{
RESEARCH OF HEAVY METALS LEACHING FROM SEDIMENTS AFTER FERITIZATION PROCESSING OF GALVANIC SLUDGE
}

\begin{abstract}
Summary. Possibility of environmental safety increasing for industrial enterprises as a result of resource-saving technology implementation for processing galvanic sludge is considered. An experimental study of stability for sediments after ferritization processing of galvanic sludge and exhausted technological solutions was carried out. As a result of dynamic leaching of heavy metal ions, the immobilization properties of sediments were determined, which were obtained at different technological parameters of the ferritization process. It is shown that the level of immobilization of heavy metals in ferritic sediments has significantly higher values in comparison with sediments of traditional wastewater neutralization. It was found, that the precipitate obtained at following key parameters of reaction mixture for the ferritization process: the total concentration of heavy metal ions $10.41 \mathrm{~g} / \mathrm{dm}^{3}$; ratio of concentrations of iron ions to total concentration of other heavy metals ions 4/1 and $\mathrm{pH}$ value of 10.5, is characterized by the highest degree of immobilization of heavy metals in the sediments of $99.96 \%$ mass. Using the results of a complete factorial experiment, regression equation for the leaching of heavy metal ions (iron, nickel, copper and zinc) from ferrite sediments was obtained: ratio of iron concentrations to the total concentration of other heavy metals and the $\mathrm{pH}$ value of reaction mixture. The adequacy of coefficients of regression equations was evaluated according to the criteria of Student and Fisher, which with $95 \%$ reliability correspond to the experimental results of the study. The proposed calculation algorithm provides an opportunity to increase efficiency and automation of ferritization process. Subsequent use of the research results will allow to implement reliable utilization of ferritized galvanic waste by application them into the row materials for obtaining alkaline cements for special purposes.

Keywords: galvanic waste; ferritization; leaching; heavy metals
\end{abstract}

(с) Д.М. Самченко, Л.І. Потапенко, Г.М. Кочетов, О.Ю. Ковальчук, А. Васильєв, О.М. Нечипор, 2021 
Д.М. Самченко ${ }^{1}$, Л.І. Потапенко ${ }^{2}$, Г.М. Кочетов ${ }^{1}$, О.Ю. Ковальчук ${ }^{1}$, А. Васильєв ${ }^{3}$, О.М. Нечипор ${ }^{1}$

${ }^{1}$ Київський національний університет будівництва і архітектури, м. Київ, Україна

${ }^{2}$ Київський національний університет імені Тараса Шевченка, м. Київ, Україна

${ }^{3}$ Державний університет Східного Теннессі, США

\title{
ДОСЛІДЖЕННЯ ВИЛУГОВУВАННЯ ВАЖКИХ МЕТАЛІВ ІЗ ПРОДУКТІВ ФЕРИТИЗАЦІЙНОӤ ПЕРЕРОБКИ ГАЛЬВАНІЧНИХ ШЛАМІВ
}

\begin{abstract}
Анотація. Розглядається перспектива підвищення рівня екологічної безпеки промислових підприємств в результаті реалізації ресурсозберігаючої технології переробки гальванічних иламів. Проведено експериментальне дослідження стійкості осадів феритизаиійної переробки гальванічних шламів $i$ відпрацьованих технологічних розчинів. $B$ результаті динамічного вилуговування іонів важких металів визначено іммобілізаційні властивості осадів, які отримані при різних технологічних параметрах процесу феритизації. Показано, щуо рівень іммобілізації важких металів у феритних осадах має суттєво вищі значення в порівнянні з осадами традиційної нейтралізаиії стічних вод. Встановлено, що осад, який отриманий при наступних ключових параметрах реакиійної сумімі для проведення процесу

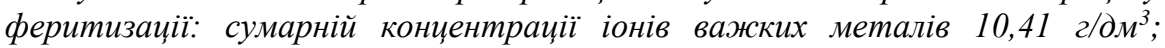
співвідношенні концентрацій іонів феруму до сумарної концентраџії інших важких металів 4/1 та величині рН 10,5, характеризується найвищим ступенем іммобілізації важких металів в осаді 99,96\% мас. Використовуючи результати повного факторного експерименту, отримано рівняння регресії залежностей вилуговування іонів важких металів (феруму, нікелю, міді та цинку) із феритних осадів від співвідношення концентрацій іонів феруму до сумарної концентрації інших важких металів та величини рН реакційної суміші. Проведена оцінка адекватності коефіцієнтів рівнянь регресії за критеріями Стьюдента та Фішера, які з надійністю 95\% відповідають експериментальним результатам дослідження. Запропонований алгоритм розрахунку надає можливість підвищення ефективності та автоматизаџії феритизачійного процесу. Використання результатів дослідження дозволить реалізувати надійну утилізачію феритизованих гальванічних відходів шляхом їх введення в шихту для отримання лужних цеементів спеціального призначення.
\end{abstract}

Ключові слова: гальванічні відходи; феритизаџія; вилуговування; важкі метали

DOI: https://doi.org/10.32347/2411-4049.2021.3.76-87

\section{Вступ}

Серед пріоритетних напрямків досліджень в галузі природно-техногенної безпеки в багатьох країнах особлива увага приділяється заходам з переробки та знешкодження токсичних відходів. Однією з гострих екологічних проблем $\epsilon$ утворення та накопичення гальванічного шламу в результаті очистки стічних вод гальванічного виробництва. Щорічно в Україні на промислових підприємствах накопичуються тисячі тонн цих токсичних відходів (табл. 1) [1]. Обсяги цих відходів 3 кожним роком постійно зростають, тоді як темпи їх переробки та утилізації незрівнянно малі. Такі відходи утворюються при 
реагентному очищенні стічних вод або утилізації робочих розчинів, в яких містяться іони важких металів. Гальванічний шлам після процесу нейтралізації має II-III клас небезпеки, у його складі містяться важкорозчинні гідроксиди важких металів [2]. Висока щільність розміщення гальванічних шламів на промислових майданчиках і розташування на значних територіях міської зони дозволяють оцінити їх як джерело високого техногенного впливу на складові навколишнього природного середовища [3]. При зберіганні таких шламів на відкритій поверхні під впливом атмосферних опадів іони важких металів вилуговуються з місць їх накопичення у грунт та водні об’єкти. Тому, неналежне зберігання таких шламів завдає невиправних збитків усій екосистемі.

Таблиця 1 - Поводження з відходами за класифікаційними угрупованнями Державного класифікатора відходів, які накопичилися у 2020 році, тонн

\begin{tabular}{|c|l|c|c|c|}
\hline № п/п & \multicolumn{1}{|c|}{ Найменування відходів } & $\begin{array}{c}\text { Обсяг } \\
\text { утворених } \\
\text { відходів }\end{array}$ & $\begin{array}{c}\text { Обсяг } \\
\text { Обсяг } \\
\text { утилізації } \\
\text { видалених } \\
\text { помислових } \\
\text { відходів у } \\
\text { спеціальні місця }\end{array}$ \\
\hline 1 & $\begin{array}{l}\text { Шлам гідроокису кольорових } \\
\text { металів після нейтралізації }\end{array}$ & 390,3 & - & - \\
\hline 2 & $\begin{array}{l}\text { Шлами гальванічні з осаджувачем } \\
\text { лугом (NаОН) }\end{array}$ & 50,0 & - & 0,5 \\
\hline 3 & $\begin{array}{l}\text { Розчини травильні кислі, } \\
\text { відпрацьовані у процесі } \\
\text { оброблення металів та нанесення } \\
\text { покриттів на метали }\end{array}$ & 2924,7 & 12,3 & 39,6 \\
\hline 4 & $\begin{array}{l}\text { Осад очисних споруд } \\
\text { гальванічного виробництва, який } \\
\text { містить оксиди кольорових } \\
\text { тяжких металів }\end{array}$ & 164,8 & 61,8 & 0,4 \\
\hline
\end{tabular}

Переробка гальванічних шламів 3 подальшим захороненням або зберіганням їх на спеціальних полігонах надто ускладнена і нерентабельна. Це спричинене тим, що існуючі технології переробки та знешкодження рідких токсичних відходів вимагають застосування багатостадійних процесів 3 використанням великої кількості хімічних реагентів, електроенергії i потребують значних капітальних вкладень. Крім того, при складуванні гальванічних шламів в накопичувачах, окрім збитку довкіллю, втрачається велика кількість цінної сировини. Повторне використання вилучених 3 шламів матеріалів, навпаки, дозволяє у відчутних кількостях зекономити природні ресурси і понизити навантаження на екосистему [4]. Тому зараз активно ведуться наукові дослідження та розробляються технології, які передбачають ресурсозберігаючу переробку та утилізацію гальванічних відходів як завершальну стадію на гальванічному виробництві.

\section{Аналіз останніх досліджень і публікацій}

Одним 3 перспективних методів переробки рідких i пастоподібних гальванічних відходів $\epsilon$ метод феритизації. Саме такий метод 
використовується в роботі [5], в якій досліджується можливість хімічної стабілізації шламів при утворенні малотоксичних феритів важких металів сполук IV класу небезпеки. Їх можна складувати на відкритих майданчиках без загрози забруднення довкілля. Феритизаційний процес передбачає трансформацію сполук дво- і тривалентного заліза та інших важких металів, при окисленні реакційної суміші киснем повітря. Крім того, цей метод забезпечує високий ступінь вилучення іонів важких металів 3 рідких промислових відходів [6].

Аналіз літературних даних показав, що на відміну від нейтралізації гальванічних шламів можливості утилізації феритизаційних осадів значно розширюються. Їх можна використовувати у виробництві магнітом'яких високочастотних матеріалів [7], феромагнітних тканин [8], а також радіопоглинаючих покриттів [9], в яких вимоги до структури феритного матеріалу строго регламентовані. Як альтернатива $є$ також безпосереднє використання феритних осадів у виробництві лужних цементів спеціального призначення [10]. Попередні дослідження показали, що такі цементи $€$ стійкими до дії агресивного середовища та мають значний спектр унікальних експлуатаційних властивостей. Лужні цементи надійно фіксують у своїй структурі радіоактивні та важкі метали не тільки на фізичному, але і на хімічному рівні [11]. В роботі [12] показано можливість введення в склад лужних цементів як наповнювача феритного осаду в межах від 5,5 до 7,5\% мас. (вміст фази фериту металів в осаді $\geq 90 \%$ ). Відхилення міцності отриманих лужних цементів від стандартних аналогів не перевищує 5\%.

Встановлено, що переробка промислових стічних вод і гальванічних шламів методом феритизації здійснюється при температурі вище $60{ }^{\circ} \mathrm{C}$ з тривалістю процесу більше години [13]. 3 огляду на суттєву енергоємність та ресурсозатратність термічного способу активації процесу, альтернативою йому може слугувати енергоощадна електромагнітна імпульсна (EMI) активація реакційної суміші [14].

Слід зазначити, що в роботах $[11,12]$ залишились невирішеними питання щодо стійкості феритних осадів, отриманих при різних технологічних параметрах процесу феритизації. Ось чому дослідження ступеня вилуговування важких металів 3 феритних осадів сприяє розробці екологічно безпечної їх утилізації, а отже, енерго- та ресурсозбереженню на гальванічному виробництві. Все це дозволяє стверджувати про надійність і безпечність переробки токсичних гальванічних шламів методом феритизації 3 подальшим використанням продуктів переробки у різних будівельних матеріалах. Такий метод утилізації гальванічних відходів дозволить зекономити цінну сировину та використати токсичний гальванічний шлам як товарний продукт.

Метою цієї роботи є дослідження хімічної стійкості осадів, отриманих при переробці гальванічних шламів феритизацією, та виконання математичної обробки отриманих експериментальних даних.

\section{Методика дослідження}

Для дослідження використовувалися зразки феритних осадів, які отримані в процесі переробки гальванічних відходів методом феритизації згідно 3 методикою, що наведена в [15]. Феритизація здійснювалась на лабораторних 
установках із термічною [16] та електромагнітною імпульсною (ЕMI) [15] активацією процесу при температурах $75{ }^{\circ} \mathrm{C}$ i $18{ }^{\circ} \mathrm{C}$, відповідно. Використовували наступні технологічні параметри процесу феритизації: сумарна концентрація іонів важких металів $\mathrm{C}_{\Sigma}=6,41 \div 14,23$ г/дм ${ }^{3}$; співвідношення концентрацій іонів феруму $\left[\mathrm{Fe}^{\text {заг. }}\right]\left(\left[\mathrm{Fe}^{2+}\right]+\left[\mathrm{Fe}^{3+}\right]\right)$ до сумарної концентрації іонів інших важких металів у розчині $\left(\Sigma \mathrm{Me}=\left[\mathrm{Ni}^{2+}\right]+\left[\mathrm{Cu}^{2+}\right]+\left[\mathrm{Zn}^{2+}\right]\right) \mathrm{Z}=2 \div 6$; величина $\mathrm{pH}=8,5 \div 10,5$; тривалість процесу $\tau=25$ хв.

Хімічну стійкість цих феритних осадів визначали шляхом вилуговування іонів важких металів у дистильованій воді, згідно з вимогами EN 12457-1:2002 Part 1. Вилуговування проводилося протягом 1 доби в динамічному режимі, який має місце при дії атмосферних опадів на шлам, що знаходиться на звалищах. Для цього використовували установку для перемішування зразків осадів зі швидкістю обертання 9 об/хв, яка представлена в роботі [17].

Для дослідження використовували зразок феритного осаду із масою $\mathrm{M}_{\mathrm{D}}$ 0,175 кг \pm 0,005 кг. Наважку поміщали в пляшку з поліпропілену об'ємом 0,5 дм³ $^{3}$ Потім додавали необхідний об'єм вилуговувача - дистильованої води L, що встановлюється в процесі екстракції співвідношенням рідина/тверда речовина, яке дорівнює 2 дм $3 /$ кг $\pm 2 \%$. Відносна величина вилуговування іонів важких металів (А) у мг на кг осаду визначається формулою (1):

$$
A=C_{\text {зал. }} \cdot\left[\left(\frac{L}{M_{D}}\right)+\left(\frac{M C}{100}\right)\right],
$$

де $L$ - об'єм вилуговувача, дм³;

$M C$ - коефіцієнт вмісту вологи, \%;

$M_{D}$ - маса сухої речовини в зразку осаду, кг;

$A$ - кількість вилугованого компонента, мг/кг;

$C_{\text {зал. }}$ - залишкова концентрація компонента в елюаті, мг/дм³

Величину $\mathrm{pH}$ елюату визначали за допомогою приладу $\mathrm{pH} 150$. В дослідженнях використовувалася дистильована вода із значенням $\mathrm{pH}$ 6,0 та електропровідністю $<5$ мкСм/см.

Залишкові концентрації іонів важких металів (феруму, нікелю, міді і цинку) після вилуговування важких металів в елюаті визначали на спектрофотометрі Hach DR 3900.

Рентгенофазовий аналіз осадів проводили на дифрактометрі Ultima IV. Досліджувані осади мають наступний склад: ферити важких металів $\mathrm{Fe}_{2}(\mathrm{Fe}, \mathrm{Ni}, \mathrm{Cu}, \mathrm{Zn}) \mathrm{O}_{4}$ в кількості від $60 \div 80 \%$, оксигідроксид заліза-нікелю $(\mathrm{FeNi}) \mathrm{O}(\mathrm{OH})-10 \div 20 \%$ та сульфат натрію $\mathrm{Na}_{2} \mathrm{SO}_{4}-10 \div 20 \%$.

Для планування експерименту, в якому реалізуються всі можливі поєднання рівнів факторів, використовували повний факторний експеримент (ПФЕ) [18]. ПФЕ моделюється для кодованих факторів $Z_{\mathrm{i}}$, які можуть приймати тільки два дискретних значення +1 ; -1 (верхній та нижній рівень, відповідно), і розраховується за формулою (2) і (3).

Для розрахунків коефіцієнтів $\mathrm{a}_{\mathrm{j}}(\mathrm{j}=0,1,2)$ для факторів $Z$ ПФЕ застосовували рівняння регресії:

$$
y=a_{o}+a_{1} Z_{1}+a_{2} Z_{2}
$$




$$
a_{j}=\frac{\sum_{i=1}^{n} Z_{i j} \cdot y_{i}}{n}, i=0,1,2 \text {; }
$$

де $y_{i}$ - значення параметра оптимізації в $i$-му досліді;

$n$ - кількість дослідів $(n=4)$.

Коефіцієнти рівняння регресії обчислювали за допомогою програми лінійного пакету “Microsoft Excel 14.0”. Перевірку значимості коефіцієнтів проводили за допомогою критеріїв Стьюдента та Фішера [19].

\section{Результати дослідження}

Вивчення вилуговування іонів важких металів з феритних осадів дозволяє визначити хімічну стійкість цих матеріалів, а отже, встановити їх екологічну безпечність. Як показують результати дослідження (табл. 2, 3), вилуговування іонів важких металів 3 отриманих осадів головним чином залежить від технологічних параметрів феритизації і способів активації реакційної суміші. Аналізуючи дані табл. 2, слід зазначити, що найнижчі значення концентрацій іонів $\mathrm{Fe}^{\text {заг. }}, \mathrm{Ni}^{2+}, \mathrm{Cu}^{2+}$ та $\mathrm{Zn}^{2+}$ в елюаті при вилуговуванні їх 3 осадів, які отримані при $\mathrm{pH}=10,5$. Крім того, ці концентрації іонів металів відповідають вимогам ДСанПіН 2.2.7.029-99 та Директиві 86/278/ЄС щодо їх ГДК у грунті. Це свідчить про надійну фіксацію цих токсичних металів у складі феритних новоутворень із стійкою кристалічною структурою оберненої шпінелі. Слід зазначити, що перевищення зазначених вище нормативів при вилуговуванні іонів $\mathrm{Ni}^{2+}$ та $\mathrm{Cu}^{2+}$ спостерігається при їх осадженні з реакційної суміші, яка має $\mathrm{pH}=8,5$. Як видно з табл. 2, вилуговування іонів важких металів з осадів, які отримані при послідовному підвищенні величини $\mathrm{pH}$ від 8,5 до 10,5, зменшується. В порівнянні з традиційним термічним способом, використання електромагнітної імпульсної активації реакційної суміші в процесі феритизації призводить до незначного збільшення вилуговування іонів $\mathrm{Fe}^{3 а г}, \mathrm{Cu}^{2+}$ та $\mathrm{Zn}^{2+}$ 3 осадів в межах $0,1 \div 0,9$ мг/кг. Інша тенденція спостерігається при вилуговуванні іонів $\mathrm{Ni}^{2+}$ : їх концентрація приблизно в 2 рази більша при термічному способі активації в порівнянні з електромагнітним імпульсним в усьому досліджуваному діапазоні $\mathrm{pH}$.

Таблиця 2 - Результати вилуговування важких металів з осадів феритизації при різних величинах $\mathrm{pH}$

\begin{tabular}{|c|c|c|c|c|c|c|c|c|c|}
\hline \multirow{2}{*}{\multicolumn{2}{|c|}{$\begin{array}{c}\text { Умови } \\
\text { проведення } \\
\text { феритизації } \\
\end{array}$}} & \multicolumn{8}{|c|}{ Вилуговування важких металів (А) з феритних осадів, мг/кг } \\
\hline & & \multicolumn{8}{|c|}{ Спосіб активації процесу феритизації } \\
\hline \multirow{2}{*}{$\mathrm{pH}$} & \multirow{2}{*}{$\begin{array}{c}\mathrm{Z} \\
(\mathrm{Fe} / \mathrm{Me})\end{array}$} & \multicolumn{4}{|c|}{ Електромагнітний імпульсний } & \multicolumn{4}{|c|}{ Термічний } \\
\hline & & $\mathrm{Fe}^{\text {zar. }}$ & $\mathrm{Ni}^{2+}$ & $\mathrm{Cu}^{2+}$ & $\mathrm{Zn}^{2+}$ & $\mathrm{Fe}^{3 a r}$ & $\mathrm{Ni}^{2+}$ & $\mathrm{Cu}^{2+}$ & $\mathrm{Zn}^{2+}$ \\
\hline 8,5 & \multirow{3}{*}{$4 / 1$} & 0,45 & 5,42 & 3,11 & 1,15 & 0,33 & 13,0 & 2,36 & 0,93 \\
\hline 9,5 & & 0,32 & 3,61 & 0,94 & 0,58 & 0,30 & 7,75 & 0,91 & 0,42 \\
\hline 10,5 & & 0,21 & 0,47 & 0,83 & 0,41 & 0,20 & 0,78 & 0,72 & 0,33 \\
\hline
\end{tabular}


Аналіз даних, які наведені в табл. 3, свідчить про те, що найменші значення вилуговування іонів важких металів із осадів спостерігаються при проведенні процесу феритизації із $\mathrm{Z}=4 / 1 \mathrm{та} \mathrm{pH}=10,5$. Концентрації цих іонів в елюаті знаходяться в межах $0,20 \div 0,83$ мг/кг. При суттєвому збільшенні концентрації іонів $\mathrm{Fe}^{\text {заг. }}$ в розчині $(\mathrm{Z}=6 / 1)$ вилуговування іонів важких металів хоч і сягає максимальних значень, але залишається в рамках вимог стандартів ДСанПіН 2.2.7.029-99 та Директиви 86/278/СС.

Таблиця 3 - Результати вилуговування важких металів з осадів феритизації при різних співвідношеннях іонів феруму до інших важких металів (Z)

\begin{tabular}{|c|c|c|c|c|c|c|c|c|c|}
\hline \multirow{2}{*}{\multicolumn{2}{|c|}{$\begin{array}{c}\text { Умови } \\
\text { проведення } \\
\text { феритизації }\end{array}$}} & \multicolumn{8}{|c|}{ Вилуговування важких металів (А) з феритних осадів, мг/кг } \\
\hline & & \multicolumn{8}{|c|}{ Спосіб активації процесу феритизації } \\
\hline \multirow{2}{*}{$\begin{array}{c}\mathrm{Z} \\
(\mathrm{Fe} / \mathrm{Me})\end{array}$} & \multirow{2}{*}{$\mathrm{pH}$} & \multicolumn{4}{|c|}{ Електромагнітний імпульсний } & \multicolumn{4}{|c|}{ Термічний } \\
\hline & & $\mathrm{Fe}^{\text {3ar. }}$ & $\mathrm{Ni}^{2+}$ & $\mathrm{Cu}^{2+}$ & $\mathrm{Zn}^{2+}$ & $\mathrm{Fe}^{3 \mathrm{ar}}$ & $\mathrm{Ni}^{2+}$ & $\mathrm{Cu}^{2+}$ & $\mathrm{Zn}^{2+}$ \\
\hline $2 / 1$ & \multirow{3}{*}{10,5} & 0,48 & 0,54 & 1,32 & 0,29 & 0,34 & 0,86 & 1,29 & 0,23 \\
\hline $4 / 1$ & & 0,21 & 0,47 & 0,83 & 0,41 & 0,20 & 0,78 & 0,72 & 0,33 \\
\hline $6 / 1$ & & 0,94 & 0,64 & 2,63 & 1,22 & 0,49 & 1,74 & 2,44 & 0,95 \\
\hline
\end{tabular}

В роботі параметром оптимізації $є$ значення вилуговування іонів важких металів ( $\left.\mathrm{Fe}^{\text {заг. }}, \mathrm{Ni}^{2+}, \mathrm{Cu}^{2+}, \mathrm{Zn}^{2+}\right)$ із осадів при переробці гальванічних відходів методом феритизації. При цьому визначаються раціональні технологічні параметри установки з отриманням екологічно стійких осадів.

Для результатів експериментів 3 вилуговування важких металів 3 феритних осадів, які проведені при різних технологічних параметрах феритизації з ЕМI активацією, позначимо відповідні плани ПФЕ від №1 до №4. Матриця планування і результати факторного експерименту наведені в табл. 4.

Таблиця 4 - Матриця планування ПФЕ і результати експериментів

\begin{tabular}{|c|c|c|c|c|c|c|c|}
\hline Фактори & \multicolumn{2}{|c|}{$\begin{array}{l}\text { Співвідношення } \\
\text { концентрацій }\end{array}$} & $\mathrm{pH}$ & $\begin{array}{l}\text { ПФЕ } \\
\text { №1 }\end{array}$ & $\begin{array}{l}\text { ПФЕ } \\
\text { №2 }\end{array}$ & $\begin{array}{l}\text { ПФЕ } \\
\text { №3 }\end{array}$ & $\begin{array}{l}\text { ПФЕ } \\
\text { №4 }\end{array}$ \\
\hline Позначення & \multicolumn{2}{|c|}{$\mathrm{Z}_{1}$} & $\mathrm{Z}_{2}$ & \multirow{5}{*}{\multicolumn{4}{|c|}{$\begin{array}{c}\text { Вилуговування іонів важких } \\
\text { металів } 3 \text { осадів } \\
\text { А, (мг/кг) }\end{array}$}} \\
\hline Одиниці вимірювання & \multicolumn{2}{|c|}{ відн. од. } & $\mathrm{pH}$ & & & & \\
\hline Нижній рівень (-) & \multicolumn{2}{|c|}{2} & 8,5 & & & & \\
\hline Середній рівень (0) & \multicolumn{2}{|c|}{4} & 9,5 & & & & \\
\hline Верхній рівень $(+)$ & \multicolumn{2}{|c|}{6} & 10,5 & & & & \\
\hline \multirow{2}{*}{ № досліду } & \multicolumn{3}{|c|}{ Кодування значення } & \multirow{2}{*}{$\mathrm{Fe}^{\text {заг. }}$} & \multirow{2}{*}{$\mathrm{Ni}^{2+}$} & \multirow{2}{*}{$\mathrm{Cu}^{2+}$} & \multirow{2}{*}{$\mathrm{Zn}^{2+}$} \\
\hline & $\mathrm{Z}_{0}$ & $\mathrm{Z}_{1}$ & $\mathrm{Z}_{2}$ & & & & \\
\hline 1 & + & - & - & 0,55 & 6,12 & 4,81 & 0,62 \\
\hline 2 & + & + & - & 0,48 & 0,54 & 1,32 & 0,29 \\
\hline 3 & + & - & + & 1,61 & 7,91 & 6,83 & 2,46 \\
\hline 4 & + & + & + & 0,94 & 0,64 & 2,64 & 1,22 \\
\hline
\end{tabular}

За допомогою комп'ютерної обробки результатів експерименту визначені коефіцієнти рівняння регресії, які представлені у табл. 5. 
Таблиця 5 - Коефіцієнти рівнянь регресії

\begin{tabular}{|c|c|c|c|}
\hline \multirow{2}{*}{$\begin{array}{c}\text { № } \\
\text { ПФЕ }\end{array}$} & \multicolumn{3}{|c|}{ Коефіцієнти регресії } \\
\hline & $\mathrm{a}_{0}$ & $\mathrm{a}_{1}$ & $a_{2}$ \\
\hline 1 & 0,895 & $-0,185$ & 0,380 \\
\hline 2 & 3,802 & $-3,212$ & 0,472 \\
\hline 3 & 3,900 & $-1,920$ & 0,835 \\
\hline 4 & 1,147 & $-0,392$ & 0,692 \\
\hline
\end{tabular}

Для адекватності отриманих результатів ПФЕ №1 $\div 4$ проведено зіставлення розрахункових та експериментальних даних, отриманих при ЕMI способі активації (рис. 1).

a)

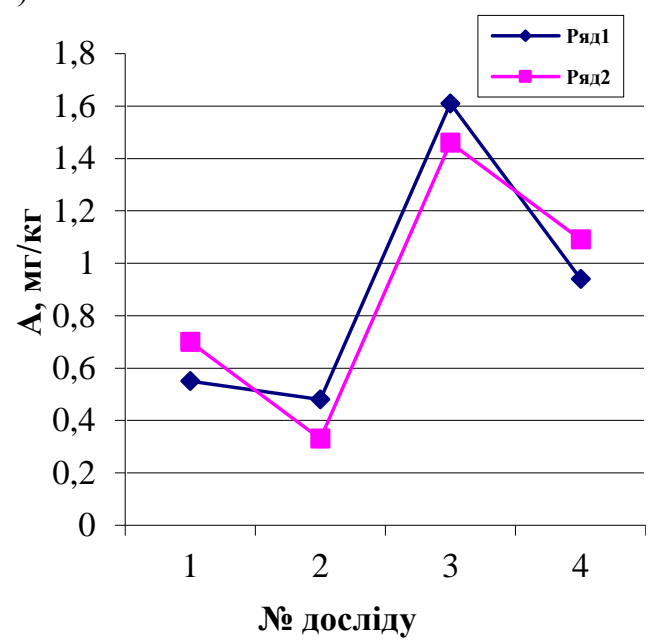

B)

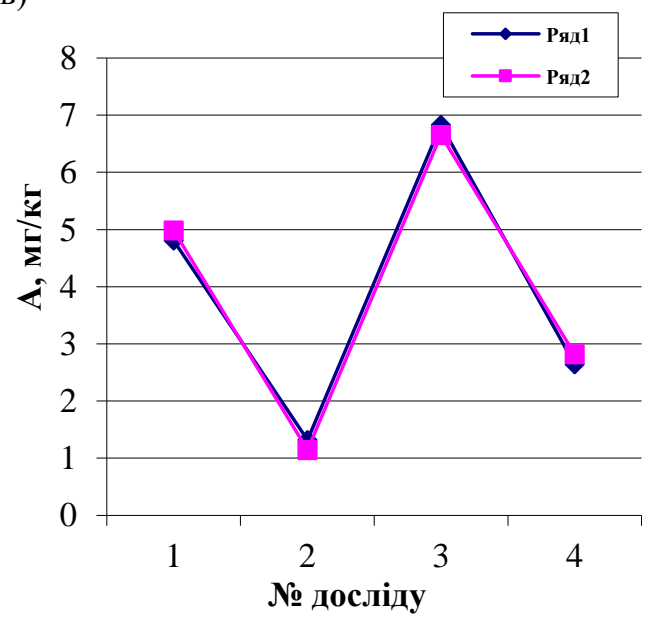

б)

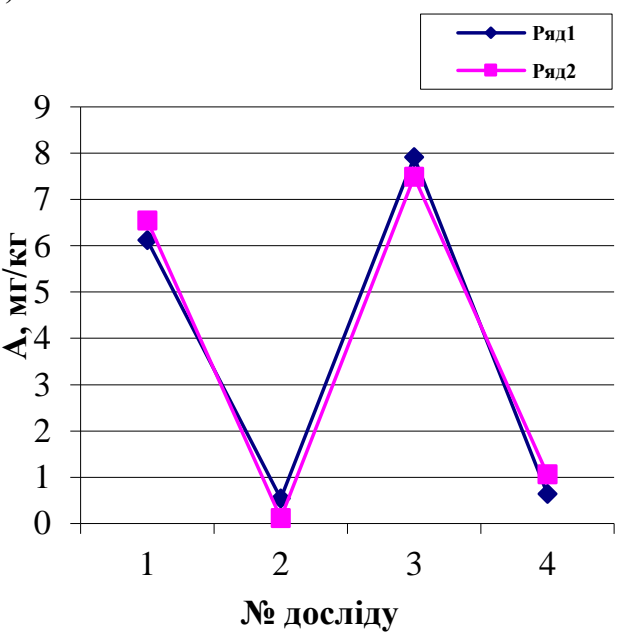

г)

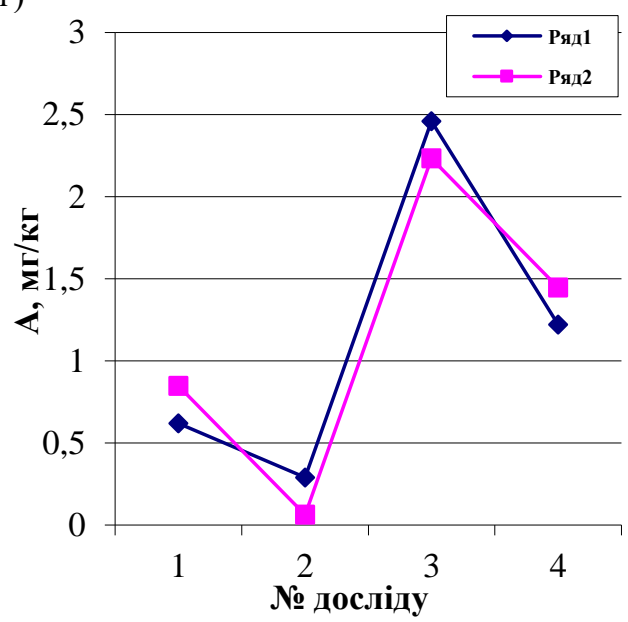

Рис. 1 - Адекватність експериментальних (Ряд 1) та розрахункових (Ряд 2) даних повного факторного експерименту: а - №1, б - №2, в - №3, г - №4

Розрахункові значення вилуговування важких металів, які наведені на рис. 1, добре узгоджуються 3 даними, отриманими експериментально. Про це 
свідчить оцінка адекватності коефіцієнтів рівнянь регресії за критеріями Стьюдента та Фішера. Запропоновані регресійні рівняння 3 надійністю 95\% адекватно описують експериментальні результати дослідження.

\section{Висновки та перспективи подальших досліджень}

Результати вилуговування іонів важких металів (феруму, нікелю, міді і цинку) 3 осадів, які отримані при різних умовах феритизації, показали надійну фіксацію цих металів у складі новоутворень із структурою оберненої шпінелі. Відмічено, що вилуговування іонів важких металів зростає при зниженні величини $\mathrm{pH}$ феритизаційного процесу від 10,5 до 8,5, що, очевидно, обумовлено зменшенням кількості кристалічних феритних фаз в осаді. Вилуговування іонів нікелю збільшується із підвищенням вмісту фази нікелевого лимоніту (FeNi)O(OH). Ця фаза $є$ нестабільною у водному розчині [15], отже, їі вміст суттєво впливає на ступінь вилуговування іонів нікелю.

Крім того, результатами досліджень показано, що для більшості важких металів $\left(\mathrm{Fe}^{\text {заг }}, \mathrm{Ni}^{2+}, \mathrm{Zn}^{2+}\right)$ найменше вилуговування металів спостерігається при співвідношенні $\mathrm{Z}(\mathrm{Fe} / \mathrm{Me})=4 / 1$ і не залежить від способу активації феритизації. Встановлено, що осад, який отриманий при електромагнітній імпульсній активації та наступних параметрах феритизації: $\mathrm{C}_{\Sigma}=10,41$ г/дм ${ }^{3} ; Z=4 / 1$, $\mathrm{pH}=10,5$, характеризується значним ступенем іммобілізації важких металів 99,96\% на відміну від гальванічних шламів, у яких це значення менше ніж 97,8\%. Концентрації важких металів після їх вилуговування з феритних осадів відповідають як вітчизняним, так і міжнародним вимогам стандартів щодо їх ГДК в питній воді та грунті.

Використовуючи результати повного факторного експерименту, отримано рівняння регресії залежностей вилуговування іонів важких металів із осадів від технологічних параметрів процесу переробки відходів феритизаційним методом. Встановлено, що розрахункові значення добре узгоджуються 3 даними експерименту. Про це свідчить проведена оцінка адекватності коефіцієнтів рівнянь регресії за критеріями Стьюдента та Фішера: регресійні рівняння 3 надійністю 95\% адекватні експериментальним даним. Запропонований алгоритм розрахунку надає можливість підвищення ефективності та автоматизації феритизаційного процесу, зокрема, його ключових технологічних параметрів. В результаті суттєво зменшується вартість переробки гальванічного шламу та отримуються екологічно безпечні феритні осади. Слід зазначити, що ці осади можливо використовувати для створення екологічно безпечних матеріалів спеціального призначення.

\section{СПИСОК ЛІТРАТУРИ}

1. Держстат України, 1998 - 2021.

2. Wastewater Treatment from Galvanization Industry with Zinc recovery / Zueva S., Ferella F., Ippolito N.M., Ruduka E., De Michelis I. // E3S Web of Conferences. 2021. Vol. 247. 01064. URL: https://doi.org/10.1051/e3sconf/202124701064.

3. Thermal stability of inorganic pigments synthesized from galvanic sludge / Marcus M.-I., Vlad M., Deak G., Moncea A., Panait A.-M., Movileanu G. // Revista de Chimie. 2020. Vol. 71(8). C. 13-20. URL: https://doi.org/10.37358/rc.20.8.8274.

4. Lanthanum oxide application for modifying the properties of chemically resistant ceramics produced with galvanic sludge additive / Vitkalova I.A., Uvarova A.S., Pikalov E.S., 
Selivanov O.G. // International Journal of Emerging Trends in Engineering Research. 2020. Vol. 8(8). C. 4544-4547. URL: https://doi.org/10.30534/ijeter/2020/81882020.

5. Catalytic and photocatalytic properties of zinc-nickel ferrites / Tsvetkov M.P., Milanova M.M., Cherkezova-Zheleva Z.P., Abrashev M.V., Mitov I.G. // Journal of Chemical Sciences. 2021. Vol. 133, Issue (1). 24. URL: https://doi.org/10.1007/s12039-020-01882-2.

6 . Copper ferrite heterojunction coatings empower polyetheretherketone implant with multimodal bactericidal functions and boosted osteogenicity through synergistic photo Fentontherapy / Zhang J., Gao X., Ma D., Xie L., Deng Y. // Chemical Engineering Journal. 2021. Vol. 422. 130094. URL: https://doi.org/10.1016/j.cej.2021.130094.

7. Evolution of microstructure and mechanical properties of $\mathrm{Cr}$ ferrite/martensite steels with different Si content after long-term aging at $550{ }^{\circ} \mathrm{C} /$ Zhang Y., He H., Wang H., Chen G., An X., Wang Y. // Journal of Alloys and Compounds. 2021. Vol. 873. 159817. URL: https://doi.org/10.1016/j.jallcom.2021.159817.

8. Ferritization-Based Treatment of Zinc-Containing Wastewater Flows: Influence of Aeration Rates / Yemchura B., Kochetov G., Samchenko D., Prikhna T. // Environmental Science and Engineering. 2021. C. 171 - 176. URL: https://doi.org/10.1007/978-3-030-51210-1_29.

9. Magnetic properties of Fe-based soft magnetic composite with insulation coating by resin bonded Ni-Zn ferrite nanofibres / Birčáková Z., Füzer J., Kollár P., Bureš R., Fáberová M. // Journal of Magnetism and Magnetic Materials. 2019. Vol. 485, C. 1-7. URL: DOI: https://doi.org/10.1016/j.jmmm.2019.04.060.

10. Woven fabrics containing hybrid yarns for shielding electromagnetic radiation / Marciniak K., Grabowska K., Stempien Z., Rutkowska A., Taranek D. // Fibres and Textiles in Eastern Europe. 2016. Vol. 24(6), Issue 120. C. 109-115. URL: DOI: https://doi.org/10.5604/12303666.1221744.

11. Radio-Absorbing Nanocoatings on Corrugated Surfaces / Antipov V.B., Potekaev A.I., Vorozhtsov A.B., Melentyev S.V., Tsyganok Y.I. // Russian Physics Journal. 2016. Vol. 59, Issue 8. C. 1225-1230. URL: DOI: https://doi.org/10.1007/s11182-016-0895-4.

12. Krivenko P.V., Kovalchuk, O., Kyrychok V.I., Guziy S.G. Sulfate resistance of alkali activated cements / Materials science forum. 2015. Vol. 865, pp. 95-106. DOI: https://doi.org/10.4028/www.scientific.net/MSF.865.95.

13. Kovalchuk O., Kochetov G., Samchenko D. Study of service properties of alkali-activated cement using wastewater treatment residues // IOP Conference Series: Materials Science and Engineering. 2019. Vol. 708, Issue 1. 012087. https://doi.org/10.1088/1757-899X/708/1/012087. 14. Development of a technology for utilizing the electroplating wastes by applying a ferritization method to the alkaline-activated materials / Kovalchuk O., Kochetov G., Samchenko D., Kolodko A. // Eastern-European Journal of Enterprise Technologies. 2019. Vol. 2/10, Issue 98. P. 27-34. doi: https://doi.org/10.15587/1729-4061.2019.160959.

15. Development of ferritization processing of galvanic wastes with energy saving electromagnetic pulse activation of the process / Kochetov G., Prihna T., Samchenko D., Kovalchuk O. // Eastern-European Journal of Enterprise Technologies. 2019. Vol. 6, Issue 102. C. 6-14. URL: https://doi.org/10.15587/1729-4061.2019.184179.

16. Yemchura B., Kochetov G., Samchenko D. Ferrit cleaning of waste water from zinc ions: influence of aeration rate // Problems of Water supply, Sewerage and Hydraulic. 2018. Vol. 30, C. 14-22. URL: https://doi.org/10.32347/2524-0021.2018.30.14-22.

17. Kochetov G., Kovalchuk O., Samchenko D. Development Of Technology Of Utilization Of Products Of Ferritization Processing Of Galvanic Waste In The Composition Of Alkaline Cements // Eastern-European Journal of Enterprise Technologies. 2020. Vol. 5, Issue (10-107). C. 6-13. URL: https://doi.org/10.15587/1729-4061.2020.215129.

18. Статюха Г.О., Складанний Д.М., Бонаренко О.С. Вступ до планування оптимального експерименту // Навч. посібн. ІВЦ «Політехніка». 2011. С. 117.

19. Бахрушин В.С. Методи аналізу даних // Навч. посібн. 2011. С. 268.

Стаття надійшла до редакиії 11.03 .2021 і прийнята до друку після рещензування 17.06.2021 


\section{REFERENCES}

1. Derzhstat Ukrainy. (1998-2021) [in Ukrainian].

2. Zueva, S., Ferella, F., Ippolito, N.M., Ruduka, E., \& De Michelis, I. (2021). Wastewater Treatment from Galvanization Industry with Zinc recovery. E3S Web of Conferences, 247, 01064. https://doi.org/10.1051/e3sconf/202124701064.

3. Marcus, M.-I.,Vlad, M., Deak, G., Moncea, A., Panait, A.-M., \& Movileanu, G. (2020). Thermal stability of inorganic pigments synthesized from galvanic sludge. Revista de Chimie, 71(8), 13-20. https://doi.org/10.37358/rc.20.8.8274.

4. Vitkalova, I.A., Uvarova, A.S., Pikalov, E.S., \& Selivanov, O.G. (2020) Lanthanum oxide application for modifying the properties of chemically resistant ceramics produced with galvanic sludge additive. International Journal of Emerging Trends in Engineering Research, 8(8), 4544-4547. https://doi.org/10.30534/ijeter/2020/81882020.

5. Tsvetkov, M.P., Milanova, M.M., Cherkezova-Zheleva, Z.P., Abrashev, M.V., \& Mitov, I.G. (2021). Catalytic and photocatalytic properties of zinc-nickel ferrites. Journal of Chemical Sciences, 133(1), 24. https://doi.org/10.1007/s12039-020-01882-2.

6. Zhang, J., Gao, X., Ma, D., Xie, L., \& Deng, Y. (2021). Copper ferrite heterojunction coatings empower polyetheretherketone implant with multi-modal bactericidal functions and boosted osteogenicity through synergistic photo Fenton-therapy. Chemical Engineering Journal, 422, 130094. https://doi.org/10.1016/j.cej.2021.130094.

7. Zhang, Y., He, H., Wang, H., Chen, G., An, X., \& Wang, Y. (2021). Evolution of microstructure and mechanical properties of $\mathrm{Cr}$ ferrite/martensite steels with different $\mathrm{Si}$ content after long-term aging at $550{ }^{\circ} \mathrm{C}$. Journal of Alloys and Compounds, 873, 159817. https://doi.org/10.1016/j.jallcom.2021.159817.

8. Yemchura, B., Kochetov, G., Samchenko, D., \& Prikhna, T. (2021). Ferritization-Based Treatment of Zinc-Containing Wastewater Flows: Influence of Aeration Rates. Environmental Science and Engineering, 171-176. https://doi.org/10.1007/978-3-03051210-1_29.

9. Birčáková, Z., Füzer, J., Kollár, P., Bureš, R., \& Fáberová, M. (2019). Magnetic properties of Fe-based soft magnetic composite with insulation coating by resin bonded $\mathrm{Ni}$ $\mathrm{Zn}$ ferrite nanofibres. Journal of Magnetism and Magnetic Materials, 485, 1-7. DOI: https://doi.org/10.1016/j.jmmm.2019.04.060.

10. Marciniak, K., Grabowska, K., Stempien, Z., Rutkowska, A., \& Taranek, D. (2016). Woven fabrics containing hybrid yarns for shielding electromagnetic radiation. Fibres and Textiles in Eastern Europe, 24(6), 120, 109-115. DOI: https://doi.org/10.5604/12303666.1221744.

11. Antipov, V.B., Potekaev, A.I., Vorozhtsov, A.B., Melentyev, S.V., \& Tsyganok, Y.I. (2016). Radio-Absorbing Nanocoatings on Corrugated Surface. Russian Physics Journal, 59(8), 1225-1230. DOI: https://doi.org/10.1007/s11182-016-0895-4.

12. Krivenko, P.V., Kovalchuk, O.Yu., Kyrychok, V.I., \& Guziy, S.G. (2015). Sulfate resistance of alkali activated cements. Materials science forum, 865, 95-106. DOI: https://doi.org/10.4028/www.scientific.net/MSF.865.95.

13. Kovalchuk, O., Kochetov, G., \& Samchenko, D. (2019). Study of service properties of alkali-activated cement using wastewater treatment residues. IOP Conference Series: Materials Science and Engineering, 708 (1). 012087. https://doi.org/10.1088/1757-899X/708/1/012087. 14. Kovalchuk, O., Kochetov, G., Samchenko, D., \& Kolodko, A. (2019). Development of a technology for utilizing the electroplating wastes by applying a ferritization method to the alkaline-activated materials. Eastern-European Journal of Enterprise Technologies, 2/10, 98, 27-34. doi: https://doi.org/10.15587/1729-4061.2019.160959.

15. Kochetov, G.M., Prikhna, T.O., Samchenko, D.M., \& Kovalchuk, O.Yu. (2019). Development of ferritization processing of galvanic waste with energy saving electromagnetic pulse activation of the process. Eastern-European Journal of Enterprise Technologies, 6/10, 102, 6-14. DOI: https://doi.org/10.15587/1729-4061.2019.184179. 
16. Yemchura, B., Kochetov, G., \& Samchenko, D. (2018). Ferrit cleaning of waste water from zinc ions: influence of aeration rate. Problems of Water supply, Sewerage and Hydraulic, 30, 14-22. https://doi.org/10.32347/2524-0021.2018.30.14-22.

17. Kochetov, G., Kovalchuk, O., \& Samchenko, D. (2020). Development of Technology of Utilization of Products of Ferritization Processing of Galvanic. Waste In The Composition of Alkaline Cements. Eastern-European Journal of Enterprise Technologies, 5(10-107), 6-13. https://doi.org/10.15587/1729-4061.2020.215129.

18. Statiukha, H.O., Skladannyi, D.M., \& Bonarenko, O.S. (2011). Introduction to planning the optimal experiment. IVC «Politekhnika» [in Ukrainian].

19. Bakhrushyn, V.Ie. (2011). Methods of data analysis [in Ukrainian].

The article was received 11.03.2021 and was accepted after revision 17.06.2021

\section{Самченко Дмитро Миколайович}

кандидат технічних наук, старший науковий співробітник науково-дослідної частини Київського національного університету будівництва і архітектури Адреса робоча: 03037 Україна, м. Київ, пр. Повітрофлотський, 31 ORCID ID 0000-0003-3305-8180 e-mail: sama30071988@gmail.com

\section{Потапенко Леонід Іванович}

кандидат технічних наук, старший науковий співробітник Київського національного університету імені Тараса Шевченка

Адреса робоча: 01033 Україна, м. Київ, вулиця Володимирська, 60

ORCID ID 0000-0003-0176-6094 e-mail: lpotapenko@ukr.net

\section{Кочетов Геннадій Михайлович}

доктор технічних наук, професор кафедри хімії Київського національного університету будівництва і архітектури

Адреса робоча: 03037 Україна, м. Київ, пр. Повітрофлотський, 31

ORCID ID 0000-0003-0041-7335 e-mail: gkochetov@gmail.com

\section{Ковальчук Олександр Юрійович}

кандидат технічних наук, старший науковий співробітник

Науково-дослідний інститут в'яжучих речовин і матеріалів

Київський національний університет будівництва і архітектури

Адреса робоча: 03037 Україна, м. Київ, пр. Повітрофлотський, 31

ORCID ID 0000-0001-6337-0488 e-mail: kovalchuk.oyu@gmail.com

\section{Васильсв Олексій}

доктор, професор Державного університету Східного Теннессі

Адреса робоча: PO Box 70695, Johnson City, TN 37614, USA

ORCID ID 0000-0003-2687-0672 e-mail: vasiliev@etsu.edu

\section{Нечипор Оксана Михайлівна}

кандидат технічних наук, асистент Київського національного університету будівництва і архітектури

Адреса робоча: 03037 Україна, м. Київ, пр. Повітрофлотський, 31

ORCID ID 0000-0001-8635-2231 e-mail: okschena@ukr.net 